\title{
Development and Performance Evaluation of Solar Powered Lawn Mower
}

\author{
Yomesh Sinha* and S.M. Mathur \\ Department of Farm Machinery and Power Engineering, CTAE, MPUAT, \\ Udaipur, Rajasthan, India \\ *Corresponding author
}

\begin{abstract}
A B S T R A C T
Due to the continuous increase in the cost of fuel and the effect of emission of gases from the burnt fuel into the atmosphere, this necessitated the use of the abundant solar energy from the sun as a source of power to drive a lawn mower. A solar powered lawn mower was designed and developed, based on the general principle of mowing. The designed solar powered lawnmower comprises of direct current (D.C) motor, a rechargeable battery, solar panel, a stainless steel blade and control switch. Performance evaluation of the developed machine was carried out with different thickness of blade and different height of cut. The machine was found to have a maximum field efficiency of $78.06 \%$ with $3 \mathrm{~mm}$ and $5 \mathrm{~mm}$ blade thickness and $50 \mathrm{~mm}$ height of cut and minimum field efficiency was $71.93 \%$ with $4 \mathrm{~mm}$ blade thickness and $25 \mathrm{~mm}$ height of cut. Maximum effective field capacity of mower was $0.0306 \mathrm{ha} / \mathrm{h}$ with 3 and $5 \mathrm{~mm}$ blade thickness and $50 \mathrm{~mm}$ height of cut and minimum effective field capacity was $0.0282 \mathrm{ha} / \mathrm{h}$ with $4 \mathrm{~mm}$ blade thickness and $25 \mathrm{~mm}$ height of cut. Power consumption observed at no load condition was 36 watt for each blade. The maximum power consumption at load condition was 264 watt with $5 \mathrm{~mm}$ thickness of blade and $25 \mathrm{~mm}$ height of cut and minimum power consumption at load condition was observed with $3 \mathrm{~mm}$ thickness of blade and $50 \mathrm{~mm}$ height of cut.
\end{abstract}

\section{Introduction}

The first lawn mower was invented by Edwin budding in 1830 in Thrupp, just outside Stroud, in Gloucestershire, England. Budding's mower was designed primarily to cut the grass on sports grounds an extensive garden, as a superior alternative to the scythe, and was granted a British patent on August 31, 1830. Research have showed that the rotary lawn mowers are more effective than the reel mowers because of it clean mowing and provision for collecting grass. The most important part of the rotary mower is the cutting blade. Rotary mowers generally have opening by the side of the housing through which cut grasses are expelled. The blade is seldom sharp enough to give a neat cut. The blade simply tears the grass resulting in brown tips. However, the horizontal blades are easy to remove and sharpen or replace. Most electric mowers available at present are 
very inconvenient in that they require the use of an extension cord which invariably gets in the way of mowing the lawn. This lawn mower cannot be used in the rural areas where is no electricity. If we are talking about the internal combustion mower they emit the pollutant and harmful gases which are mostly responsible for environmental pollution and cause the greenhouse gases effect believed to be responsible for the worsening global warming of our planet.

Efficient use of solar energy can significantly reduce the scarcity of our day to day energy requirement for present as well as future generations. An example of how solar energy can be harvested by implementing it with the available technology is shown with an example of solar operated lawn mower. Nowadays pollution is a major issue for whole world. Pollution is manmade and can be seen in own homes. In case gas powered lawn mowers due to the emission of gases it is responsible for pollution. Also the cost of fuel is increasing hence it is not efficient. So the solar powered lawn mower is introduced. Solar powered lawn mower can be described as the application of solar energy to power an electric motor which in turn rotates a blade which does the mowing of a lawn.

The solar powered lawn mower is better than that powered by internal combustion engines, because it eliminates the emission of gases of an internal combustion mower which are mostly responsible for environmental pollution. This is so because solar energy is green/renewable energy. It does not require a gasoline refill or occasional replacement of spark plugs.

\section{Working principal of machine}

The solar panel convert Solar energy into electrical energy by photovoltaic effect and will be stored in battery. Electric energy of the battery will be converted to mechanical energy through a set of blade designed to achieve cutting operation. The electric circuit ensures the power transmission from the battery to D.C. motor. The cutting blade is connected to output shaft of the D.C. motor with the help of coupler. The motor is connected to the battery through connecting wires, in this connection on/off switch is provided to start and stop the motor and toggle switch is also provided to control the direction of blade (clockwise \& anti clockwise). The rotating blade will continuously cut the grass and mower is propelled forward by the operator.

\section{Materials and Methods}

Theoretical calculations while selecting machine parts

\section{Mass of blade}

The area of blade $=$ length $\mathrm{x}$ width $\left(\mathrm{m}^{2}\right)$

$$
\begin{aligned}
& =0.35 \times 0.04 \\
& =0.014\left(\mathrm{~m}^{2}\right)
\end{aligned}
$$

Volume $=$ area $\mathrm{x}$ thickness $\left(\mathrm{m}^{3}\right)$

$$
\begin{aligned}
& =0.014 \times 0.003 \\
& =4.2 \times 10^{-5}\left(\mathrm{~m}^{3}\right)
\end{aligned}
$$

Mass of blade $=$ density $\mathrm{x}$ volume $(\mathrm{kg})$

$$
=7922 \times 4.2 \times 10^{-5}
$$$$
=0.3327 \mathrm{~kg}
$$

\section{Weight of cutting blade}

The weight of blade, $\mathrm{W}=\mathrm{Mg}(\mathrm{N})$

$$
\begin{aligned}
& \mathrm{W}=0.3327 \times 9.81 \\
& \mathrm{~W}=3.26 \mathrm{~N}
\end{aligned}
$$

Where,

$$
\begin{aligned}
& \mathrm{M}=\text { mass of the blade }(\mathrm{kg}) \\
& \mathrm{g}=\text { acceleration due to gravity }
\end{aligned}
$$

\section{Torque required to rotating the blade}

$$
\begin{aligned}
& \mathrm{T}=\mathrm{Wr}(\mathrm{Nm}) \\
& \mathrm{T}=3.26 \times 0.175 \\
& \mathrm{~T}=0.5705 \mathrm{Nm}
\end{aligned}
$$


Where,

$$
\begin{aligned}
& \mathrm{W}=\text { weight of the blade }(\mathrm{N}) \\
& \mathrm{r}=\text { radius of the blade }(\mathrm{m})
\end{aligned}
$$

\section{Motor selection}

12 volt and 26 amp motor selected for operation

$$
\begin{aligned}
& \mathrm{P}=\mathrm{VI} \\
& \mathrm{P}=12 \times 26 \\
& \mathrm{P}=312 \text { watt } \\
& \mathrm{P}=2 \pi \mathrm{NT} / 60 \text { watt }
\end{aligned}
$$

Where,

$$
\begin{aligned}
& \mathrm{P}=\text { power }(\text { watt }) \\
& \mathrm{N}=\text { speed of motor in } \mathrm{rpm} \\
& \mathrm{T}=\text { torque } \\
& \mathrm{T}=\mathrm{Px} 60 / 2 \pi \mathrm{N} \\
& \mathrm{T}=1.98 \mathrm{Nm}
\end{aligned}
$$

Net force acting on the blade

$$
\begin{aligned}
& \mathrm{F}=\mathrm{T} / \mathrm{r} \\
& \mathrm{F}=1.98 / 0.175 \\
& \mathrm{~F}=11.31 \mathrm{~N}
\end{aligned}
$$

Where,

$$
\begin{aligned}
& \mathrm{T}=\text { torque } \\
& \mathrm{r}=\text { radius of blade }
\end{aligned}
$$

\section{Battery selection}

12 volt $26 \mathrm{AH}$ battery selected for operating the motor

At full load condition discharging time

$$
\begin{aligned}
& =26 / 26 \\
& =1 \text { hour }
\end{aligned}
$$

\section{Solar panel selection}

12 volt 60 watt panel selectedfor charging the battery

$$
\begin{aligned}
& \mathrm{I}=\mathrm{P} / \mathrm{V} \\
& \mathrm{I}=60 / 12 \\
& \mathrm{I}=5 \mathrm{amp}
\end{aligned}
$$

Charging time $=26 / 5$

$$
=5.2 \text { hour }
$$

\section{Components of mower}

The Solar powered lawn mower consists of following components.

D.C. motor

Battery

Solar panel

Cutting blade

Coupler

Switch board

Push handle

Wheel

\section{D.C. motor}

A D.C. motor is a mechanically commutated electric motor powered from direct current. The stator is stationary in space by definition and therefore so is its current. The current in the rotor is switched by the commentator to also be stationary in space. The speed of a D.C. motor can be controlled by changing the voltage applied to the armature or by changing the field current. It was the heart of the developed lawn mower, D.C. motor was used for rotating the cutting blade. The motor shaft was connected to the blade shaft with the help of coupler. According to force requirement to cut the grass we have used 12 volt, 400 watt D.C. motor.

\section{Battery}

Battery is energy storage device. The energy of the battery was used to run the motor. The size of battery was selected on the size of motor used, so according to motor size 12 volt $26 \mathrm{AH}$ rechargeable battery was used to rotate the motor

\section{Solar panel}

A solar panel is a set of solar photovoltaic modules electrically connected and mounted on a supporting structure. A photovoltaic 
module is a packaged, connected assembly of solar cells. The solar panel can be used as a component of a larger photovoltaic system to generate and supply electricity in commercial and residential applications. Solar panel converts the solar energy to the electrical energy by photovoltaic principle and this energy is used to charge the battery. Power generation by the Solar panel is depend on the area of the panel receive the sun rays, so according to the requirement we have used the Solar panel 12 volt and 60 watt. While selecting the solar panel we considered,

The average sun hours per day,

Size of battery,

Current draw by the motor,

Frequency and duration of use the mower.

\section{Cutting blade}

In designing the cutting blade, the force required to cut the lawn mower as well as the force acting on the blade was considered. The force required by any sharp object to have impact on the grass should not less than 10 Newton. It is also dependent on the height, density and the area covered by the object (Atkins, 1984). Therefore, in designing the blade of the solar powered lawn mower, the force required for effective mowing should be greater than 10 Newton.

\section{Coupler}

Coupler is a holding device which was used for connecting the motor shaft to the blade shaft. One end of the coupler was connected to the motor shaft and another end was connected with the blade shaft. In another end of coupler 3 holes were there to adjust the height of

\section{Switch board}

It has two types of switch, the first one is on/off switch which was used to control start and stop the motor and the second one is toggle switch which was used to rotate the blade in clockwise and anticlockwise direction.

\section{Push handle}

Handle is attached to the main frame at suitable position. Some arrangement was there to adjust the height of the handle according to the height of the operator.

\section{Wheel}

Wheel is provided on the main frame. With the help of this the machine travels one place to another place.

\section{Results and Discussion}

Based on requirement, result of past research and scientific principles, a Solar powered lawn mower was developed. The developed mower consists of D.C. motor, rechargeable battery, Solar panel, cutting blades and transport wheel. The developed mower was tested in lawn with different blades and different height of cut to evaluate its performance. The results of performance evaluation are presented in table.

In conclusion, the functional performance of lawn mower was satisfactory during field. Lawn mower can be successfully used for lawn grasses and forage crops. The lawn mower takes little more time for covering area because of its less working width. Lawn mower gives fairly uniform height of cutting. The performance of lawn mower was also satisfactory in economical point of view. 
Table.1 Performance of lawn mower

\begin{tabular}{|l|c|c|c|c|c|c|}
\hline S. No. & $\begin{array}{c}\text { Thickness of } \\
\text { blade }\end{array}$ & $\begin{array}{c}\text { Height of } \\
\text { (mm) }\end{array}$ & $\begin{array}{c}\text { Operating } \\
\text { (mpeed }\end{array}$ & $\begin{array}{c}\text { T.F.C. } \\
\text { (ha/h) }\end{array}$ & $\begin{array}{c}\text { E.F.C. } \\
\text { (ha/h) }\end{array}$ & $\begin{array}{c}\text { Field } \\
\text { efficiency } \\
(\mathbf{m} / \mathbf{m})\end{array}$ \\
\hline $\mathbf{1 .}$ & 3 & 25 & 1.12 & 0.0392 & 0.0291 & 74.23 \\
\hline $\mathbf{2 .}$ & 3 & 37.5 & 1.12 & 0.0392 & 0.0300 & 76.53 \\
\hline $\mathbf{3 .}$ & 3 & 50 & 1.12 & 0.0392 & 0.0306 & 78.06 \\
\hline $\mathbf{4 .}$ & 4 & 25 & 1.12 & 0.0392 & 0.0288 & 73.46 \\
\hline $\mathbf{5 .}$ & 4 & 37.5 & 1.12 & 0.0392 & 0.0294 & 75.00 \\
\hline $\mathbf{6 .}$ & 4 & 50 & 1.12 & 0.0392 & 0.0303 & 77.29 \\
\hline $\mathbf{7 .}$ & 5 & 25 & 1.12 & 0.0392 & 0.0285 & 72.70 \\
\hline $\mathbf{8 .}$ & 5 & 37.5 & 1.12 & 0.0392 & 0.0291 & 74.23 \\
\hline $\mathbf{9 .}$ & 5 & 50 & 1.12 & 0.0392 & 0.0300 & 76.53 \\
\hline
\end{tabular}

Table- Power consumption of lawn mower with different thickness of blade and different height of cut

\begin{tabular}{|l|c|c|c|c|}
\hline S. No. & $\begin{array}{c}\text { Thickness of blade } \\
(\mathbf{m m})\end{array}$ & $\begin{array}{c}\text { Height of cut } \\
\text { (mm) }\end{array}$ & \multicolumn{2}{|c|}{$\begin{array}{c}\text { Power consumption } \\
\text { (watt) }\end{array}$} \\
\hline & & & At no load & At load \\
\hline $\mathbf{1 .}$ & 3 & 25 & 36 & 240 \\
\hline $\mathbf{2 .}$ & 3 & 37.5 & 36 & 192 \\
\hline $\mathbf{3 .}$ & 3 & 50 & 36 & 120 \\
\hline $\mathbf{4 .}$ & 4 & 25 & 36 & 252 \\
\hline $\mathbf{5 .}$ & 4 & 37.5 & 36 & 204 \\
\hline $\mathbf{6 .}$ & 4 & 50 & 36 & 264 \\
\hline $\mathbf{7 .}$ & 5 & 25 & 36 & 216 \\
\hline $\mathbf{8 .}$ & 5 & 37.5 & 36 & 144 \\
\hline $\mathbf{9 .}$ & 5 & 50 & 36 & \\
\hline
\end{tabular}

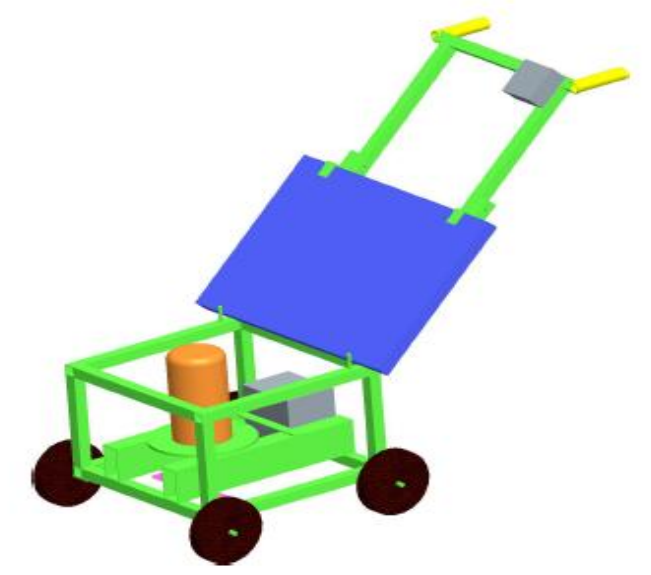

Fig.1 3D model of lawn mower 


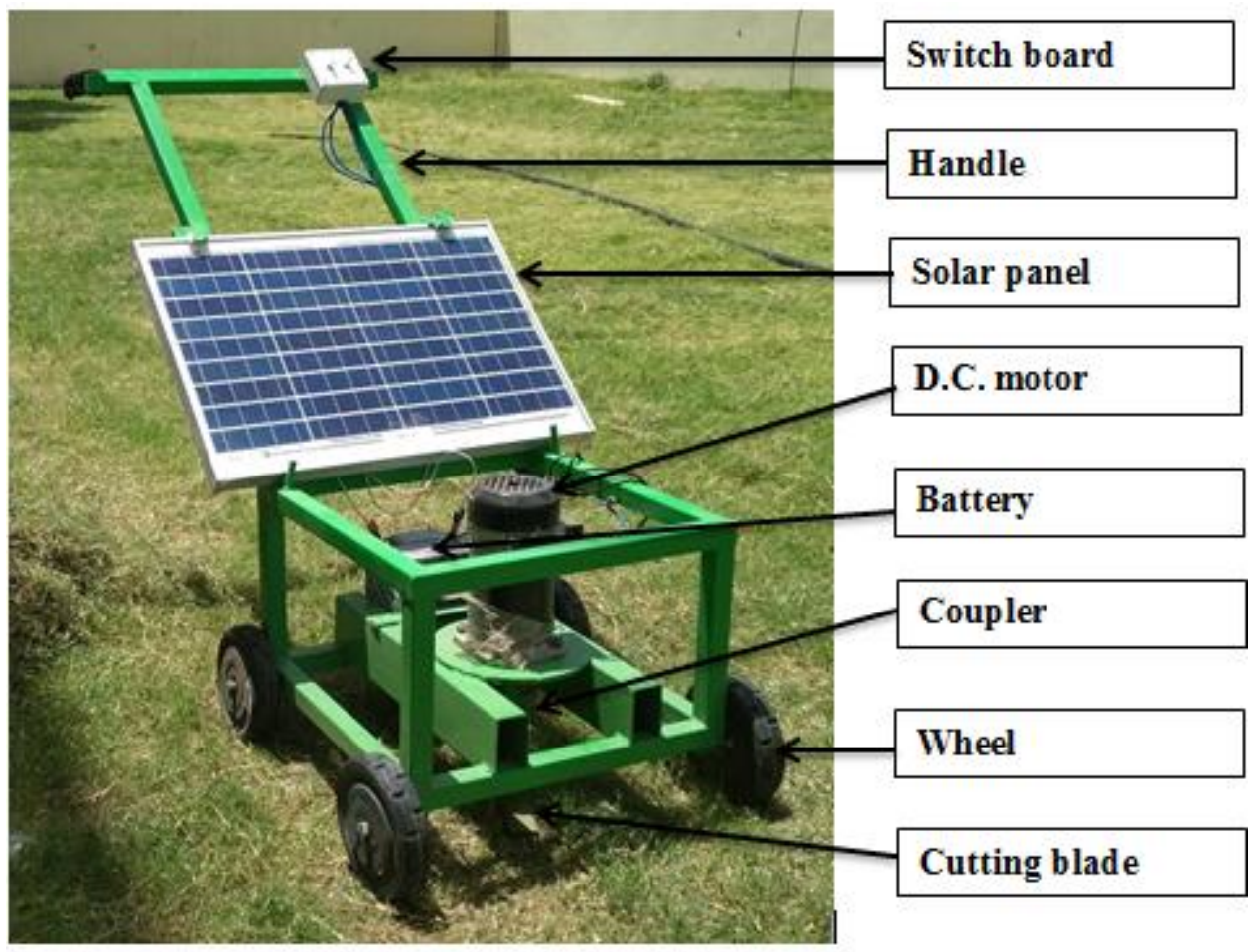

Fig.2 Developed machine

In view of results obtained by field operations performed by Solar powered lawn mower was summarized it can be concluded that,

Functional performance of solar powered lawn mower was highly satisfactory in properly prepared lawns and fields.

Since the handle of the machine is adjustable therefore it can easily operate by men as well as women according to their height.

The field capacity of is quite high and its field efficiency was impressive.

The cost of machine was reasonably low as compared to engine operated lawn mower.

\section{References}

Atkins, R. 1984. Lawnmower and Garden equipment. Creative Homeowner Press, United Kingdom. pp. 22.

Dalal, S.S., Sonune, V.S., Gawande, D.B., Shere, S.B. and Wagh, S.A. 2016.
Manufacturing of solar grass cutter. International Journal of Research in Advance Technology, 1: 352-355.

Danve, V., Bose, A. and Dhawan, V. 2016. Solar powered gardener. International Journal of Technical Research and Application, 1: 39-43.

Dutta, P.P., Baruah, A., Konwar, A. and Kumar, V. 2016. A technical review of lawn mower technology. $A D B U$ Journal of Engineering Technology, 4: 179-182.

Gupude, A., Hatwade, A., Wankhede, S.T. and Ingle, A.H. 2017. Design and fabrication of reel lawn mower cycle. International Journal of Research in Science \& Engineering, 3: 66-69.

Nagarajan, N., Sivakumar, N.S. and Saravanan S. 2017. Design and fabrication of lawn mower. Asian Journal of Applied Science and Technology, 1: 50-54.

Ogiemudia, O.G., Sadjere, G., Chughiefe, L. and Ariavie, G. 2016. Design and 
improvement of a solar powered lawn mower from locally sourced material in Benin city, EDO state, Nigeria. ELK Asia Pacific Journal of Mechanical Research, 2: 1-11.

Okafor, Ehujuo and Igbokwe 2016. Development of a solar powered lawn mower. International Journal of Engineering and Technology, 6: 104108.

Osmani, A.R. 2014. Conventional energy to renewable enegy. North-Eastern Hill University Journal, 12: 41-60.

Pamujula, H.M. and Bhaskar, H.B. 2015. Manually operated rotary lawn mower. International Journal of Innovations in Engineering and Technology 2: 1-4.

Rai, G.D. 1995. Non-conventional sources of energy. Khanna Publishers, Delhi pp. 47-72.

\section{How to cite this article:}

Yomesh Sinha and Mathur, S.M. 2020. Development and Performance Evaluation of Solar Powered Lawn Mower. Int.J.Curr.Microbiol.App.Sci. 9(05): 3378-3384.

doi: https://doi.org/10.20546/ijcmas.2020.905.401 